\title{
Hitchhiking Halophytes in Wrack and Sediment-Laden Ice Blocks Contribute To Tidal Marsh Development in The Upper Bay of Fundy.
}

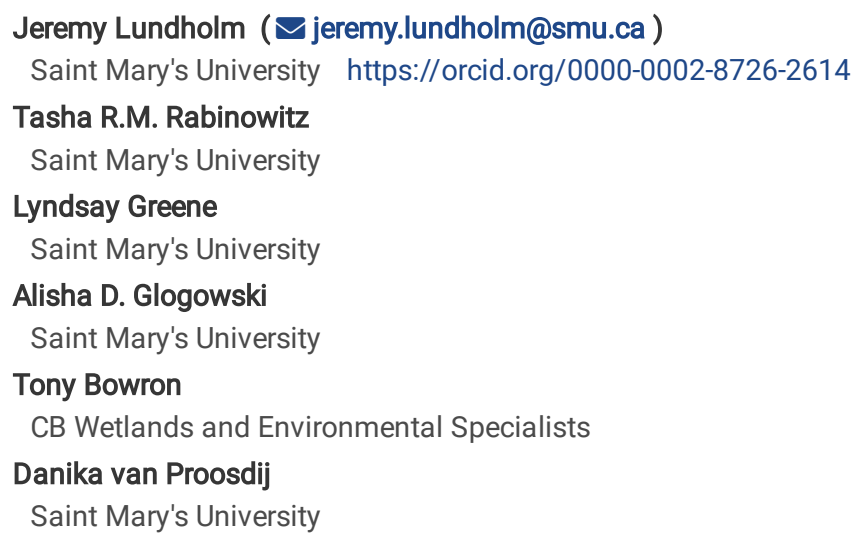

Research Article

Keywords: sediment transfer, coastal wetlands, succession, vegetation dynamics, restoration

Posted Date: October 29th, 2021

DOI: https://doi.org/10.21203/rs.3.rs-1021544/v1

License: (c) (i) This work is licensed under a Creative Commons Attribution 4.0 International License. Read Full License 


\section{Abstract}

Salt marshes are a type of coastal wetland that are affected by dynamic coastal processes. Ice blocks and wrack (mats of plant debris) regularly float onto northern marshes and become stranded, affecting vegetation and soil accretion. There is little research regarding the capacity of ice and wrack to transport viable plant propagules onto marshes where they can colonize, which may be particularly important at barren new salt marsh restoration sites. Contributions of sediment by ice may also be important at restoration sites to raise the marsh platform to elevations appropriate for plant colonization. We collected ice $(n=27)$ and wrack $(n=18)$ samples at marshes in the Bay of Fundy, ran germination trials with the contents, and measured the quantity of sediment in the ice. We found viable propagules from halophytic and non-halophytic species in wrack, and viable propagules of Sporobolus pumilus in ice. Additionally, we found sediment densities between 0.01 and $4.75 \mathrm{~g} \cdot \mathrm{cm}^{-3}$ in ice blocks that translated to 26.61 $21,483.59 \mathrm{~kg}$ of total sediment per block, representing a large source of sediment. We found that the number of germinating propagules could not be predicted by wrack size, and that $\mathrm{pH}$, sediment density, sediment weight in ice blocks were variable across the marsh surface, while ice salinity was negatively correlated with elevation and distance from creek. Our results indicate that ice and wrack represent a potential source for vegetation colonization at salt marsh sites and highlights their contributions to facilitating vegetation colonization through building marsh soils.

\section{Introduction}

Salt marshes are a type of coastal wetland affected by ocean tides, typically found along sheltered shorelines. They occur worldwide, but mainly in middle and high latitudes (Mcowen et al. 2017). A large proportion of salt marsh has been lost globally due to human-engineered barriers to tidal flow, such as dykes, improperly sized or placed tidal crossings (i.e. culverts), and coastal development. Restoration of salt marshes has been occurring with increasing frequency worldwide as evidence that salt marshes provide beneficial ecosystem services such as protection from storm surge and flooding (Möller et al. 2014), high quality habitat for fish and birds (Hicklin 1987), and climate regulation through carbon sequestration (McLeod et al. 2011) is growing.

Wrack (mats of plant debris; Figure 1) and ice (Figure 2) are two common large-scale disturbances in northern salt marshes that can be floated by the tides between and within marshes and influence marsh formation and maintenance. Wrack is typically deposited along the high tide line in spring (Reidenbaugh and Banta 1980) where it can smother vegetation and start secondary succession (Hartman et al. 1983), provide an influx of nutrients (Chapman and Roberts 2004), contribute organic matter to soils where it strands, and deposit viable plant propagules (Minchinton 2006). Ice can also alter marshes by scouring the marsh surface (Dionne 1969; Gordon Jr. and Desplanque 1983), removing and depositing sediment, plant propagules, and turfs (Argow et al. 2011; Dionne 1993; Ewanchuk and Bertness 2003), and increasing overall topographic heterogeneity (Dionne 1989; Ewanchuk and Bertness 2003; Pejrup and Andersen 2000). These disturbances have considerable effects on newly restored salt marshes.

Transport of plant propagules by wrack and ice is a function that may play an important role at early restoration sites. The effectiveness of vegetation recolonization following salt marsh restoration is affected by the presence of and distance to propagule sources, and propagule dispersal to and within sites (Rand 2000; Wolters et al. 2005). Past research has shown that wrack can transport viable plant propagules from a diverse range of species over distances greater than $2.5 \mathrm{~km}$ (Minchinton 2006), and ice has been the suspected source of plant colonization at newly developing salt marshes in the Bay of Fundy where there was no clear source of plant propagules (van Proosdij and Townsend 2006; Virgin et al. 2020). There is little research regarding these modes of dispersal in general, and none in our study area of the Bay of Fundy. Our study sought to confirm the viability of propagules rafting on wrack and ice to better understand the potential for these dispersal mechanisms to aid colonization at new restoration sites.

The relative elevation of the marsh platform can also influence vegetation recolonization at early restoration sites as subsided elevations can exclude plants from establishing (Garbutt et al. 2006; Rand 2000). As such, contributions of ice laden sediments to soil accretion at these sites raise the marsh platform to an elevation appropriate for plant growth and facilitates vegetation recolonization. Ice is a major contributor to the sedimentary budget in salt marshes in New England, U.S.A. (Argow et al. 2011) and the Saint Lawrence estuary in Québec (Dionne 1989, 1993), and can also alter the effects of waves on coastal erosion (Gibeault et al. 2016). Past research in the Bay of Fundy has also indicated suggested that ice makes important contributions to the sediment budget of marshes in the region (van Proosdij et al. 2006b; Macfarlane et al. 2009; Ollerhead et al. 1999). The present study compliments this research in documenting the amount of sediment transported by ice onto salt marshes in the Bay of Fundy to provide insight into its potential to facilitate vegetation colonization at new restoration sites.

\section{Methods \\ Study Region}

Ice (one site) and wrack (six sites) sampling occurred in the Minas Basin, an inlet on the Nova Scotia side of the Bay of Fundy in Canada (Figure 3; Table 1). The Bay of Fundy is a hypertidal estuary with semidiurnal tides that forms the northern extension of the Gulf of Maine. Tidal ranges in the Minas Basin can be higher than in the main Bay and can reach up to $16 \mathrm{~m}$ (Desplanque and Mossman 2004). Because of its northern latitude, salt marshes in the Bay of Fundy are also heavily influenced by ice in the winter (Desplanque and Mossman 2004). In the Fundy region, salt marshes are mainly minerogenic due to high suspended sediment concentrations (van Proosdij et al. 2006a). They are typically stratified into two main vegetation zones, the low marsh dominated almost entirely by Sporobolus alterniflorus (Loisel.) (formerly Spartina alterniflora), and a wider high marsh zone that 
can be dominated by a range of species depending on local salinity and flooding conditions (Pratolongo et al. 2019). There is a high concentration of salt marsh restoration projects in the Fundy region (Bowron et al. 2012), some of which were utilized in this study (Table 1).

Table 1

Site locations and corresponding site descriptions.

\begin{tabular}{|c|c|c|c|c|c|c|c|}
\hline Site & $\begin{array}{l}\text { Site } \\
\text { Code }\end{array}$ & $\begin{array}{l}\text { Sample } \\
\text { Type }\end{array}$ & Lat $\left({ }^{\circ} \mathrm{N}\right)$ & Long $\left({ }^{\circ} \mathrm{E}\right)$ & $\begin{array}{l}\text { Site } \\
\text { Size } \\
\text { (ha) }\end{array}$ & Dominant Vegetation on Site & Notes \\
\hline Cogmagun & Cog & Wrack & 45.077889 & -64.131917 & 350 & $\begin{array}{l}\text { Sporobolus pumilus, Carex } \\
\text { palecea (Limonium carolinianum } \\
\text { and Solidago sempervirens also } \\
\text { present) }\end{array}$ & $\begin{array}{l}\text { Restoration site, dyke breached in } \\
2009 \text {. One wrack sample taken from } \\
\text { restoration area. }\end{array}$ \\
\hline Kingsport & $\mathrm{Kp}$ & Wrack & 45.141889 & -64.398556 & 200 & $\begin{array}{l}\text { Carex paleacea, Scirpus } \\
\text { americanus }\end{array}$ & $\begin{array}{l}\text { Historically dyked salt marsh that was } \\
\text { naturally restoring for the past century. }\end{array}$ \\
\hline Lantz & Ltz & Wrack & 45.173222 & -64.157778 & 50 & Carex paleacea & Intact salt marsh. \\
\hline Noel & $\mathrm{Nl}$ & Wrack & 45.299278 & -63.729528 & 200 & $\begin{array}{l}\text { Sporobolus pumilus, Carex } \\
\text { paleacea and Solidago } \\
\text { sempervirens }\end{array}$ & Intact salt marsh. \\
\hline Walton & Wal & Wrack & 45.221361 & -63.996444 & 350 & $\begin{array}{l}\text { Sporobolus alterniflorus, } \\
\text { Sporobolus pumilus (Carex } \\
\text { paleacea also present) }\end{array}$ & $\begin{array}{l}\text { Restoration site, dyke breached in } \\
2005 \text { (van Proosdij et al., 2010). All } \\
\text { wrack samples taken outside } \\
\text { restoration area. }\end{array}$ \\
\hline Elderkin & Eld & $\begin{array}{l}\text { Wrack } \\
+ \text { Ice }\end{array}$ & 45.003051 & -64.151929 & 40 & $\begin{array}{l}\text { Sporobolus alterniflorus, } \\
\text { Sporobolus pumilus }\end{array}$ & $\begin{array}{l}\text { Young marsh formed after } \\
\text { construction of Windsor causeway in } \\
1970 \text { (van Proosdij and Townsend, } \\
\text { 2006). }\end{array}$ \\
\hline
\end{tabular}

Ice

\section{Set-Up}

The Elderkin marsh was stratified into three zones (high marsh, low marsh, mudflats) based upon site hydrology and the presence of vegetation. Zones were delineated in ArcGIS 9.3 using a digital elevation model (DEM) referenced to Canadian Geodetic Vertical Datum 1928 (CGVD28; created from LiDAR and IKONOS satellite imagery from 2007) and aerial imagery (IKONOS satellite imagery) as follows: the high marsh zone was identified as areas with elevations between $7.57 \mathrm{~m}$ (Higher High Water Large Tide) and $5.77 \mathrm{~m}$ (Higher High Water Mean Tide), the low marsh zone was the area between $5.77 \mathrm{~m}$ elevation and the edge of vegetation, and the mudflat zone was the area between the edge of vegetation and the lower elevation bound of -0.03 m (Mean Water Level) (Figure 4). Fifteen random points were identified in each zone as target locations for sampling ice blocks.

\section{Field}

Sampling occurred on March 17, 21, and 27 2009, during spring tides. The nearest ice block within $20 \mathrm{~m}$ of each target location was sampled. Coordinates, length, width, and height of each block were recorded, and a photograph was taken. Ice blocks were broken apart using an axe to determine whether rhizomes or dead plant material were present. Two samples were taken from the ice block using a serrated knife, one from the edge of the block and one from the interior. If rhizomes were present, one of the samples was taken from that area of the block. Both samples were placed in the same plastic bag and stored in a cooler.

\section{Lab Analyses and Germination Trials}

Ice samples were melted at room temperature and rhizomes were removed, rinsed of sediment and stored in plastic bags in a refrigerator at $4^{\circ} \mathrm{C}$ for two months. Melted ice was pipetted into graduated cylinders, leaving settled sediment, to measure volume. The initial volume of ice was estimated by converting the melted volume to ice volume with a ratio obtained by measuring a bag of ice cubes' volume using water displacement, and the volume of the melted cubes. Water was then tested for $\mathrm{pH}$, salinity and conductivity using a YSI probe (model 600QS-0-0).

Sediment was left to dry and then weighed. It was then wet sieved using a $0.063 \mu \mathrm{m}$ and $0.125 \mu \mathrm{m}$ sieve to separate organic (seeds) and inorganic material. A suction filtration was performed on water samples and water from rinsed rhizomes, then filter papers dried at $105^{\circ} \mathrm{C}$ for two hours, cooled in a dessicator overnight and weighed to obtain additional sediment weights, which were added together for a total weight. The sediment slurry was retained for germination trials.

Total sediment weight in the ice blocks was calculated using sediment density in the samples and multiplying by the ice block volume (calculated by multiplying the measured dimensions of the block). Sediment density data were also compared to the sediment density of a neutrally buoyant ice block calculated using the formula: 


$$
C=\frac{\left(\rho_{w}-\rho_{i}\right)}{\left(1-\frac{\rho_{i}}{\rho_{s}}\right)}=0.163 \mathrm{~g} / \mathrm{cm}^{3}
$$

where $\mathrm{C}=$ sediment density, $\rho_{\mathrm{w}}=$ the density of sea water at $5^{\circ} \mathrm{C}\left(1.0 \mathrm{~g} / \mathrm{cm}^{3}\right.$ with salinity of $\left.29.5 \mathrm{ppt}\right), \rho_{\mathrm{i}}=$ the density of ice $\left(0.9167 \mathrm{~g} / \mathrm{cm}^{3}\right)$, and $\rho_{\mathrm{s}}=$ inorganic particle density for mean grain size of $23-30 \mu \mathrm{m}\left(2.65 \mathrm{~g} / \mathrm{cm}^{3}\right)$ to determine whether blocks were positively or negatively buoyant and therefore understand whether they were likely to be refloated after stranding on the marsh surface.

The sediment slurry was sown onto sand in trays, and rhizomes were identified to species and sown onto sand in trays and kept in a greenhouse (16:8 hour light/dark cycle and $25: 18{ }^{\circ} \mathrm{C}$ day/night temperature). Trays were watered and number of shoots was counted daily for one week and then every other day for eight weeks.

\section{Post-Processing and Statistical Analysis}

ArcMap 9.3 was used to extract the elevation at which blocks were found from the DEM. Creek thalwegs were digitized from aerial imagery and Spatial Analyst tools were used to automatically measure the distance from each block to the nearest creek. Generalized linear models were fitted in R 3.6.0 (R Core Team 2019) to compare ice block volume, sediment density and weight, distance to creek, pH and salinity in blocks among zones, and to identify relationships among variables.

\section{Wrack}

\section{Field}

Field sampling was conducted at salt marshes in Noel, Cogmagun, Walton and Lantz on June 1, 2012 and Elderkin and Kingsport on June 5, 2012. Each sampling day, recent and current tide cycles and the weather were noted. One wrack mat (>10 m long and >1 m wide; Figure 1) was located in the center, and at either end of the marsh running parallel to the water $\left(n=18\right.$; Figures R1-R6). A $1 \mathrm{~m}^{2}$ quadrat was blind tossed onto the mat and wrack depth was measured at 5 locations in a line (at the center of the quadrat, each side of the quadrat, and $5 \mathrm{~m}$ to either side of the quadrat). All wrack material inside the quadrat was collected into a garbage bag. Dominant species in the extant vegetation around the wrack mat was noted.

\section{Lab Analyses and Germination Trials}

Each sample was weighed (wet weight) and visually divided into quarters. One quarter was dried at $80^{\circ} \mathrm{C}$ for 48 hours then weighed (dry weight). Two quarters were wet sieved using a $5 \mathrm{~mm}$ and $0.2 \mathrm{~mm}$ sieve. Seeds retained in the $0.2 \mathrm{~mm}$ sieve were sewn onto sand in trays, covered with $2 \mathrm{~mm}$ of sand and kept in a greenhouse (16:8 hour light/dark cycle and $25: 18^{\circ} \mathrm{C}$ day/night temperature). Trays were watered once daily for fifteen weeks then identified and counted.

\section{Statistical Analysis}

Linear models were fitted in R 3.6.0 (R Core Team 2019) using wet weight, dry weight, and wrack depth as predictors for the total number of germinated seeds per sample.

\section{Results}

\section{Ice}

Ice blocks were found at 27 of 45 pre-determined sample points. Ice blocks on the marsh were various shapes and sizes, some consisting of multiple pieces melted together (composite ice; Figure 2a), while others were flat with a thickness of $<1 \mathrm{~m}$ (Figure $2 \mathrm{~b}$ ). There was a thin layer of snow on some blocks while others were melting and covered in sediment which was slumping off onto the marsh surface. The distribution and density of blocks across the marsh surface varied over the three sampling days, with an observed decrease in the number of blocks on the marsh over time, potentially indicative of the timing in the tide cycle. Ice blocks on the mudflats were all found in tidal creeks. Flat ice was mainly found in high marsh ( $<0.6 \mathrm{~m}$ thickness) (Figure 4). Larger ice blocks were found in the low marsh and mudflats (>0.6 $\mathrm{m}$ thickness) (Figure 4$)$, with the largest blocks found in the low marsh (Table 2; Figure 4). 
Table 2

Summary statistics for various ice block characteristics. Elevation was measured relative to CGVD28. Salinity and pH were measured using one less sample as melted samples were not a large enough volume to test.

\begin{tabular}{|c|c|c|c|c|c|c|c|c|c|c|c|c|c|c|c|}
\hline \multirow[b]{2}{*}{ Zone } & \multicolumn{2}{|c|}{$\begin{array}{l}\text { Ice Block } \\
\text { Volume }\left(\mathrm{m}^{3}\right)\end{array}$} & \multicolumn{2}{|c|}{$\begin{array}{l}\text { Sediment } \\
\text { Density } \\
\left(\mathrm{g} \cdot \mathrm{cm}^{-3}\right)\end{array}$} & \multicolumn{2}{|c|}{ Total Sediment (kg) } & \multicolumn{2}{|c|}{ Elevation (m) } & \multicolumn{2}{|c|}{$\begin{array}{l}\text { Distance to } \\
\text { Creek (m) }\end{array}$} & \multicolumn{2}{|l|}{$\mathrm{pH}$} & \multicolumn{2}{|c|}{ Salinity (ppt) } & \multirow[t]{2}{*}{$\begin{array}{l}\text { Sample } \\
\text { Size }\end{array}$} \\
\hline & Mean & SD & Mean & SD & Mean & SD & Mean & SD & Mean & SD & Mean & SD & Mean & SD & \\
\hline $\begin{array}{l}\text { High } \\
\text { marsh }\end{array}$ & 6.74 & 5.98 & 0.32 & 0.51 & 2500.79 & 4938.85 & 6.26 & 0.39 & 45.86 & 39.00 & 7.83 & 0.18 & 0.41 & 0.22 & 5 \\
\hline $\begin{array}{l}\text { Low } \\
\text { marsh }\end{array}$ & 14.77 & 11.29 & 0.35 & 0.43 & 4916.29 & 5644.19 & 5.28 & 0.44 & 34.19 & 20.15 & 7.87 & 0.23 & 1.06 & 0.66 & 16 \\
\hline Mudflats & 9.62 & 9.80 & 1.13 & 1.79 & 4812.97 & 7442.20 & 4.34 & 2.01 & 29.05 & 40.34 & 7.75 & 0.22 & 2.53 & 1.33 & 6 \\
\hline
\end{tabular}

Salinity was greater in the mudflats than low and high marsh; salinity was negatively correlated with elevation and distance from creek. Generally, two types of dominant sediment were observed in the ice: sandy mud with occasional shells, and rich organic mud containing $S$. alterniflorus rhizomes characterized by a layer of black anaerobic sediment, indicating different sources of sediment. Seventeen of the 27 ice blocks were negatively buoyant.

Of the 27 ice blocks, 9 contained rhizomes or marsh turf and 6 contained dead plant material. These blocks were found in all zones of the marsh (Figure 4). The dead plant material appeared to be mainly $S$. alterniflorus stems that had broken off at the base. Collected ice samples contained Sporobolus pumilus (Roth) P.M. Peterson \& Saarela (formerly Spartina patens) and S. alterniflorus rhizomes. Twenty-three S. pumilus shoots sprouted within five days in the greenhouse and two more shoots were observed after eight weeks. Viable rhizomes were from two ice block samples, both found in the high marsh. No seeds germinated from the sediment slurries.

\section{Wrack}

All sites contained at least some large wrack mats (Table R1), found almost entirely in the high marsh. Depth of wrack in the field ranged from 3-13 cm (average $7 \pm 1 \mathrm{~cm}$ ) (Table R1). The majority of plant debris that made up the wrack was identifiable as $S$. alterniflorus or Juncus gerardii. Seeds germinated from all samples (Table 3). There were no significant relationships between dry weight or depth of wrack and the number of germinating seeds in the samples. Overall, ten plant species grew enough to maturity to be identified and there were 1410 individuals germinating in total (Table 3 ). Many Juncus seeds germinated but few germinated from identifiable inflorescences that could be attributed to J. gerardii. Halophytic species such as J. gerardii, Solidago sempervirens and Plantago maritima were the most frequent and abundant, with a handful of weedy species and one tree seedling making up the rest (Figure 4; Table 3). The seedlings identified as belonging to the family Cyperaceae were likely Carex paleacea Schreb. ex Wahlenb. as this species was found in the extant vegetation at most sites. Similarly, the seedling identified as Juncus spp. were likely J. gerardii as this is the most common species in the area that would be affected by tidal flooding and dead material identified to that species was common in the wrack. Assuming that Juncus sp. are J. gerardii, all three identified halophytes occurred at three or more sites (Table 3).

Table 3

Halophytic status of species that germinated from wrack germination trials and corresponding sites from which they germinated.

\begin{tabular}{|lll|}
\hline Species & Site & Type \\
\hline Juncus gerardii Loisel. & $\mathrm{Nl}$ & Halophytic \\
\hline Juncus (sp) & Cog, Kp, Lz, NI & probably Halophytic \\
\hline Solidago sempervirens L. & Cog, Kp, Ltz, NI & Halophytic \\
\hline Plantago maritima L. & Cog, Ltz, Wal & Halophytic \\
\hline Cyperaceae (Carex) & Eld, Cog, Kp, Ltz, NI, Wal & probably Halophytic \\
\hline Picea glauca (Moench) Voss & $\mathrm{Nl}$, Wal & Non-Halophytic \\
\hline Sonchus sp. & $\mathrm{Nl}$ & Non-Halophytic \\
\hline Cerastium fontanum Baumg. & $\mathrm{Ltz}$ & Non-Halophytic \\
\hline Stellaria sp. & $\mathrm{Nl}$ & Non-Halophytic \\
\hline Poa compressa L. & $\mathrm{Eld}$ & Non-Halophytic \\
\hline Unknown Species G & $\mathrm{NI}$ & Unknown \\
\hline Unknown Species M & $\mathrm{Wal}$ & Unknown \\
\hline
\end{tabular}




\section{Discussion}

Our results indicate that plant propagules transported by wrack and ice in the Bay of Fundy are viable and have the potential to colonize new salt marsh sites. Viable propagules from 12 species were found in wrack across all six study sites. Plant propagules were also found in 9 of 27 ice samples, and those in two blocks were viable. In addition, we confirmed that ice can carry large amounts of sediment and has the potential to contribute significantly to marsh accretion and therefore vegetation colonization at new restoration sites or other early successional salt marshes.

Prolific seed producers tended to be best represented in germinating specimens from the wrack. These include early season annuals such as Sonchus sp., Stellaria sp., and Cerastium fontanum, as well as early season perennials (both halophytic and non-halophytic) such as Poa compressa, J. gerardii, Plantago maritima and Solidago sempervirens. Halophytic species were most abundant, mirroring communities found in salt marshes in the area (Porter et al. 2015). Wrack can form from the current season's growth or the previous season's growth, and the two forms are generally distinguishable (Reidenbaugh and Banta 1980). Since wrack was collected in the spring in our study, it is likely that all seeds were from the previous growing season. An interesting avenue for future research would be to investigate whether seeds and rhizomes deposited by wrack are produced in the current or past growing season, how this changes over the course of the season, and how this process relates to plants' dormancy requirements.

There was a distinct lack of Sporobolus spp. germinating from wrack samples, although their rhizomes did appear to be present. These are typically the dominant species in salt marshes in the study region (Porter et al. 2015) and S. alterniflorus is an ecosystem engineer frequently colonizing new restoration sites (Bruno 2000; van Proosdij et al. 2010). It is interesting that these species were not represented in the wrack since S. alterniflorus'longrange dispersal is thought to be through seed rafting on wrack (Davis et al. 2004), and S. pumilus is likely to do the same because of their similar morphologies. It is possible that Sporobolus spp. were absent from the wrack because the previous season's seeds may have shattered and been dispersed in some other way as they do not grow in seed capsules. It is also possible that seeds were present but not viable, or that larger rhizomes of these species were sieved out in our study, removing them from our germination trials. Propagules of Sporobolus spp. were, however, found in ice blocks, and S. pumilus propagules were confirmed to be viable, demonstrating ice as a potential source for these species at new restoration sites or early successional natural marshes. Though we did not find viable Sporobolus spp. in wrack or viable S. alterniflorus in ice, it is highly likely that they can be transported in this way (Davis et al. 2004; Minchinton 2006; van Proosdij and Townsend 2006) and more extensive testing would provide better information on the importance of these dispersal mechanisms for these specific species.

Physical characteristics (e.g., depth, size) of wrack mats were not predictive of the amount of germinating seeds and were highly variable among sites. Similarly, the presence of rhizomes in ice blocks was not predicted by their location on the marsh, or their size (volume, thickness). Environmental and geographical factors such as the weather, tides, season, marsh topography, and distance to neighbouring marshes could affect the physical characteristics, contents and stranding location of wrack and ice, making them somewhat unpredictable sources of plants in salt marshes and therefore difficult to harness for restoration. In addition, ice blocks are in many cases a composite of multiple freezing and stranding events at different elevations within a marsh depending on the tides, with layers of sediment and rhizome material being incorporated into the ice block matrix (Argow et al. 2011; Figure 2a). Exploring how these characteristics affect the ability of wrack and ice to transport plant propagules would increase understanding of these forces in restoration projects.

In addition to directly transporting viable plant propagules, we found that ice blocks can carry and contribute large amounts of sediment to marshes, which contributes to raising the elevations at restored marshes to levels at which inundation times are decreased enough to allow plant growth. This process might also aid in allowing intact salt marshes to accrete sediment and keep pace with sea level rise. This agrees with past research finding that ice contributes considerably to the sediment budget at salt marshes (Argow et al. 2011; Gordon Jr. and Desplanque 1983; Ollerhead et al. 1999; Pejrup and Andersen 2000; van Proosdij et al. 2006b). There was large variability in sediment densities and total sediment weights in our ice, which may be reflexive of the wide range of mechanisms through which sediment can be accumulated (e.g., deposited through settling and freezing, ice blocks freezing to the ground and ripping out marsh surface, and directly from the water where suspended sediment concentrations are high; Argow et al. 2011). We found no relationship between amounts of sediment and distance from creek or zone, indicating that large blocks with high sediment concentrations may be present anywhere on the marsh surface. These findings are in opposition to past research finding that sediment concentration in ice decreased logarithmically with distance from creek (Argow et al. 2011). This discrepancy is likely a result of the season in which ice blocks were sampled; while Agrow et al. (2011) carried out their research in the winter, we sampled nearer to spring, when temperatures were higher and many ice blocks were observed melting, effectively increasing sediment concentrations. Sediment concentrations may have also been affected by the large tidal range in the Bay of Fundy allowing heavier blocks to travel farther from creeks, or relative inundation times at blocks' stranding locations, where longer periods allowed more sediment to settle and freeze to the blocks. Though we have confirmed that ice can contribute to the sediment budget at Fundy salt marsh restoration sites, there are still some unknown factors controlling the amount of sediment that can be transported onto the marsh, and where it can be deposited.

There is conflicting information regarding the degree to which ice can travel between marshes. It has been hypothesized that once ice blocks are grounded on a marsh, they can move farther onto the marsh but are not typically removed (Pejrup and Andersen 2000; Reidenbaugh and Banta 1980); however, in Bay of Fundy systems this is not the case. In our study we observed movement and removal of ice blocks over the course of the sample period, indicating that the marcotidal Fundy tides can rapidly change the icescape on salt marshes. However, we found that the majority of sampled ice blocks were negatively buoyant and unlikely to be refloated by the tide; however, since our sample period was near the end of the winter, many of the blocks were experiencing obvious melting, which concentrated sediments and decreased the buoyancy of the blocks. Warmer winters may decrease the 
availability of ice to Fundy salt marshes. Additionally, most salt marsh restoration initiatives in the region focus on restoring tidal hydrology and fish passage (Bowron et al. 2012); while the ability of ice to enter previously restored marshes and whether future design can facilitate ice movement has been considered (e.g. wider breach openings), it has not been quantified. Further research is needed to determine how far blocks can travel in Fundy systems and the influence of factors such as winter weather, currents, topology of tidal access to wetlands such as breach dimensions and position within the estuary, and timing of the season on ice block transit.

\section{Conclusion}

Wrack and ice are both mechanisms through which viable plant material of a range of species can be deposited at new and natural salt marsh sites. These are both, however, highly unpredictable sources of plant material that can be affected by seasons, tides, and weather, among other factors. Wrack and ice may be important long-range transport mechanisms of plant propagules in Fundy systems, and they may be uniquely influenced by the conditions in the Bay of Fundy. Wrack and ice also contribute to the development of restored marsh soils which facilitates the subsequent colonization by vegetation. There are many opportunities for future research regarding these modes of plant dispersal in the Bay of Fundy which will lead to an improved understanding of ideal restoration designs and successional trajectories in the future.

\section{Declarations}

\section{Acknowledgements:}

This research was supported by National Sciences and Engineering Research Council (Canada) Discovery grants to D. van Proosdij and J. Lundholm.

\section{References}

1. Argow BA, Hughes ZJ, FitzGerald DM (2011) Ice raft formation, sediment load, and theoretical potential for ice-rafted sediment influx on northern coastal wetlands. Cont Shelf Res 31:1294-1305. https://doi.org/10.1016/j.csr.2011.05.004

2. Bowron TM, Neatt NC, van Proosdij D, Lundholm J (2012) Salt marsh tidal restoration in Canada's Maritime provinces. In: Roman CT, Burdick DM (eds) Tidal marsh restoration: A synthesis of science and management. Island Press, Washington, pp 191-209. https://doi.org/10.5822/978-161091-229-7

3. Bruno JF (2000) Facilitation of cobble beach plant communities through habitat modification by Spartina alterniflora. Ecology $81: 1179-1192$

4. Chapman MG, Roberts DE (2004) Use of seagrass wrack in restoring disturbed Australian saltmarshes. Ecol Manag Restor 5:183-190. https://doi.org/10.1111/j.1442-8903.2004.00207.x

5. Davis HG, Taylor CM, Civille JC, Strong DR (2004) An Allee effect at the front of a plant invasion: Spartina in a Pacific estuary. J Ecol $92: 321-327$. https://doi.org/10.1111/j.0022-0477.2004.00873.x

6. Desplanque C, Mossman DJ (2004) Tides and their seminal impact on the geology, geography, history, and socio-economics of the Bay of Fundy, eastern Canada. Atl Geol 40:1-65. https://doi.org/10.4138/729

7. Dionne J-C (1969) Tidal flat erosion by ice at La Pocatière, St. Lawrence estuary. J Sediment Petrol 39:1174-1181. https://doi.org/10.1086/623936

8. Dionne J-C (1989) An estimate of shore ice action in a Spartina tidal marsh, St. Lawrence Estuary, Québec, Canada. J Coastal Res 5:281-293

9. Dionne J-C (1993) Sediment load of shore ice and ice rafting potential, upper St. Lawrence Estuary, Québec, Canada. J Coastal Res 9:628-646

10. Ewanchuk PJ, Bertness MD (2003) Recovery of a northern New England salt marsh plant community from winter icing. Oecologia 136:616-626. https://doi.org/10.1007/s00442-003-1303-7

11. Garbutt RA, Reading CJ, Wolters M, Gray AJ, Rothery P (2006) Monitoring the development of intertidal habitats on former agricultural land after the managed realignment of coastal defences at Tollesbury, Essex, UK. Mar Pollut Bull 53:155-164.

https://doi.org/10.1016/j.marpolbul.2005.09.015

12. Gibeault C, Neumeier U, Bernatchez P (2016) Spatial and temporal sediment dynamics in a subarctic salt marsh (Gulf of St. Lawrence, Canada). J Coastal Res 2:1344-1361

13. Gordon DC Jr, Desplanque C (1983) Dynamics and Environmental Effects of Ice in the Cumberland Basin in the Bay of Fundy. Can J Fish Aquat Sci 40:1331-1342

14. Hartman J, Caswell H, Valiela I (1983) Effects of wrack accumulation on salt marsh vegetation. Oceanol Acta 17e:99-102

15. Hicklin PW (1987) The migration of shorebirds in the Bay of Fundy. Wilson Bull 99:540-570

16. Macfarlane CB, Drolet D, Barbeau MA, Hamilton DJ, Ollerhead J (2011) Movement of drift ice as a vector for transport of sediment and invertebrates on intertidal mudflats of the Bay of Fundy. In: Proceedings of the 16th workshop on the hydraulics of ice covered rivers, Winnipeg, Manitoba. Committee on River Ice Processes and the Environment. pp 238- 248

17. McLeod E, Chmura GL, Bouillon S, Salm R, Björk M, Duarte CM, Lovelock CE, Schlesinger WH, Silliman BR (2011) A blueprint for blue carbon: Toward an improved understanding of the role of vegetated coastal habitats in sequestering $\mathrm{CO}_{2}$. Front Ecol Environ 9:552-560. 
https://doi.org/10.1890/110004

18. Mcowen CJ, Weatherdon LV, Van Bochove JW, Sullivan E, Blyth S, Zockler C, Stanwell-Smith D, Kingston N, Martin CS, Spalding M, Fletcher S (2017) A global map of saltmarshes. Biodiversity Data Journal 5(e11764). https://doi.org/10.3897/BDJ.5.e11764

19. Minchinton TE (2006) Rafting on wrack as a mode of dispersal for plants in coastal marshes. Aquat Bot 84:372-376. https://doi.org/10.1016/j.aquabot.2006.01.007

20. Möller I, Kudella M, Rupperecht F, Spencer T, Paul M, van Wesenbeeck BK, Wolters G, Jensen K, Bouma TJ, Miranda-Lange M, Schimmels S (2014) Wave attenuation over coastal salt marshes under storm surge conditions. Nat Geosci 7:727-731.

https://doi.org/https://doi.org/10.1038/ngeo2251

21. Ollerhead J, van Proosdij D, Davidson-Arnott RGD (1999) Ice as a mchanism for contributing sediments to the surface of a marco-tidal saltmarsh, Bay of Fundy. In: Proceedings Canadian Coastal Conference, CCSEA, pp 345-358

22. Pejrup M, Andersen TJ (2000) The influence of ice on sediment transport, deposition and reworking in a temperate mudflat area, the Danish Wadden Sea. Cont Shelf Res 20:1621-1634. https://doi.org/10.1016/S0278-4343(00)00040-6

23. Porter C, Lundholm J, Bowron TM, Lemieux B, van Proosdij D, Neatt N, Graham JM (2015) Classification and environmental correlates of tidal wetland vegetation in Nova Scotia. Canada Botany 93:825-841. https://doi.org/10.1139/cjb-2015-0066

24. Pratolongo P, Leonardi N, Kirby JR, Plater A (2019) Temperate coastal wetlands: Morphology, sediment processes and plant communities. In: Perillo GME, Wolanski E, Cahoon DR, Hopkinson CS (eds) Coastal wetlands: An integrated ecosystem approach, 2nd ed., pp 105-152). Elsevier B.V. https://doi.org/10.1016/B978-0-444-63893-9.00003-4

25. R Core Team (2019) R: A language and environment for statistical computing. R Foundation for Statistical Computing. https://www.r-project.org/

26. Rand TA (2000) Seed dispersal, habitat suitability and the distribution of halophytes across a salt marsh tidal gradient. J Ecol 88:608-621. https://doi.org/10.1046/j.1365-2745.2000.00484.x

27. Reidenbaugh TG, Banta WC (1980) Origins and Effects of Spartina Wrack in a Virginia Salt Marsh. Gulf Res Rep 6:393-401. https://doi.org/10.18785/grr.0604.07

28. van Proosdij D, Davidson-Arnott RGD, Ollerhead J (2006a) Controls on spatial patterns of sediment deposition across a macro-tidal salt marsh surface over single tidal cycles. Estuar Coast Shelf S 69:64-86. https://doi.org/10.1016/j.ecss.2006.04.022

29. van Proosdij D, Ollerhead J, Davidson-Arnott RGD (2006b) Seasonal and annual variations in the volumetric sediment balance of a macro-tidal salt marsh. Mar Geol 225:103-127. https://doi.org/10.1016/j.margeo.2005.07.009

30. van Proosdij D, Townsend SM (2006) Spatial and temporal patterns of salt marsh colonization following causeway construction in the Bay of Fundy. J Coastal Res 3:1859-1863. isi:000202961500132

31. van Proosdij D, Lundholm J, Neatt N, Bowron T, Graham J (2010) Ecological re-engineering of a freshwater impoundment for salt marsh restoration in a hypertidal system. Ecol Eng 36:1314-1332. https://doi.org/10.1016/j.ecoleng.2010.06.008

32. Virgin SDS, Beck AD, Boone LK, Dykstra AK, Ollerhead J, Barbeau MA, McLellan NR (2020) A managed realignment in the upper Bay of Fundy: Community dynamics during salt marsh restoration over 8 years in a megatidal, ice-influenced environment. Ecol Eng 149(105713). https://doi.org/https://doi.org/10.1016/j.ecoleng.2020.105713

33. Wolters M, Garbutt A, Bakker JP (2005) Plant colonization after managed realignment: The relative importance of diaspore dispersal. J Appl Ecol 42:770-777. https://doi.org/10.1111/j.1365-2664.2005.01051.x

\section{Figures}




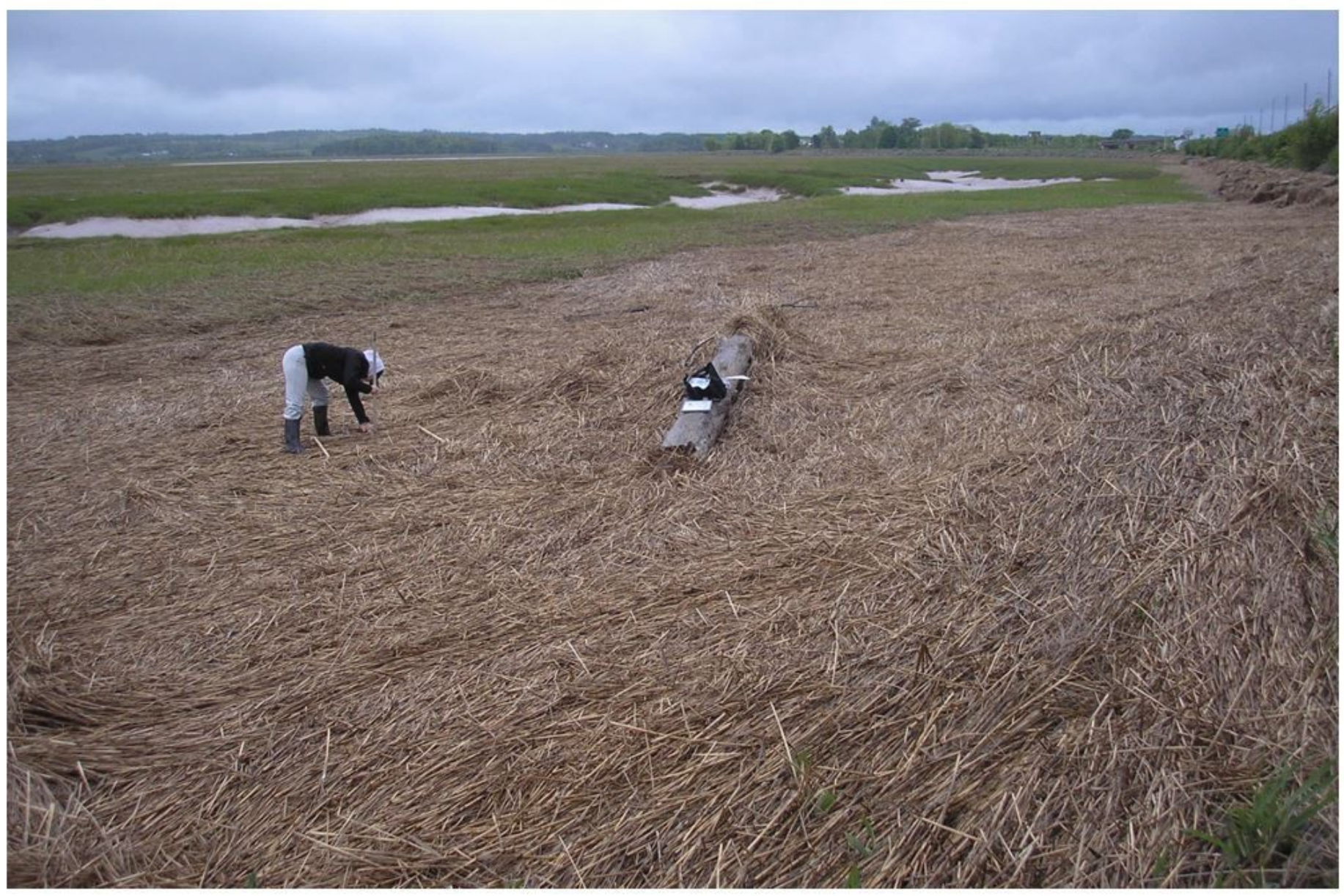

Figure 1

Photograph of a large wrack mat taken at Elderkin on June 5, 2012 by A. Glogowski. 


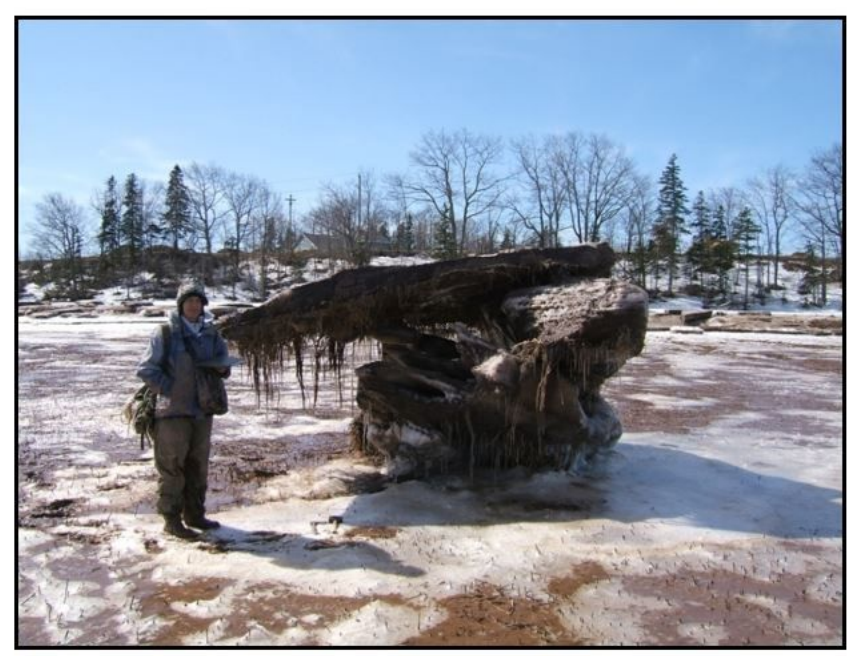

a)

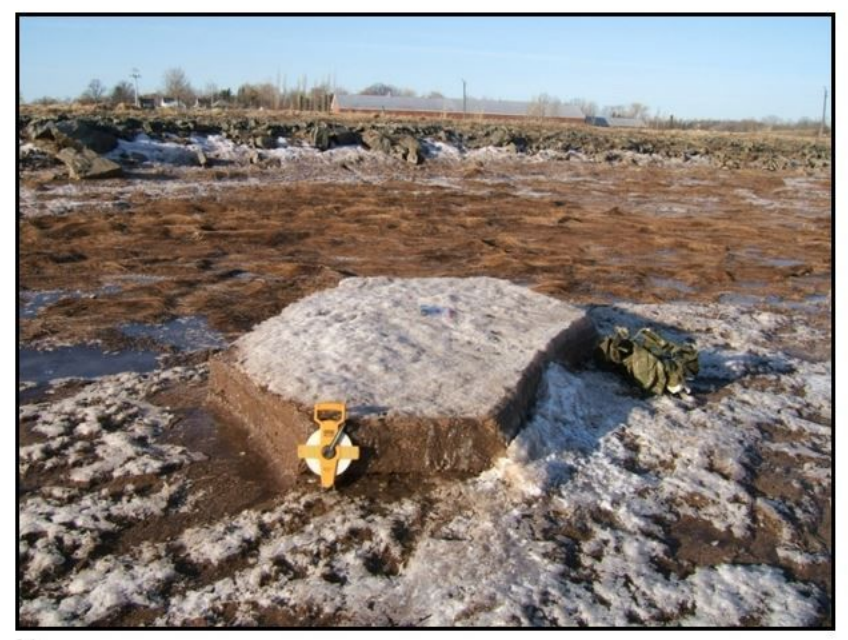

b)

\section{Figure 2}

Photographs of a) a piece of composite ice containing multiple blocks melted together and b) a flat ice raft taken at the Elderkin marsh in March, 2009 by L. Greene. 


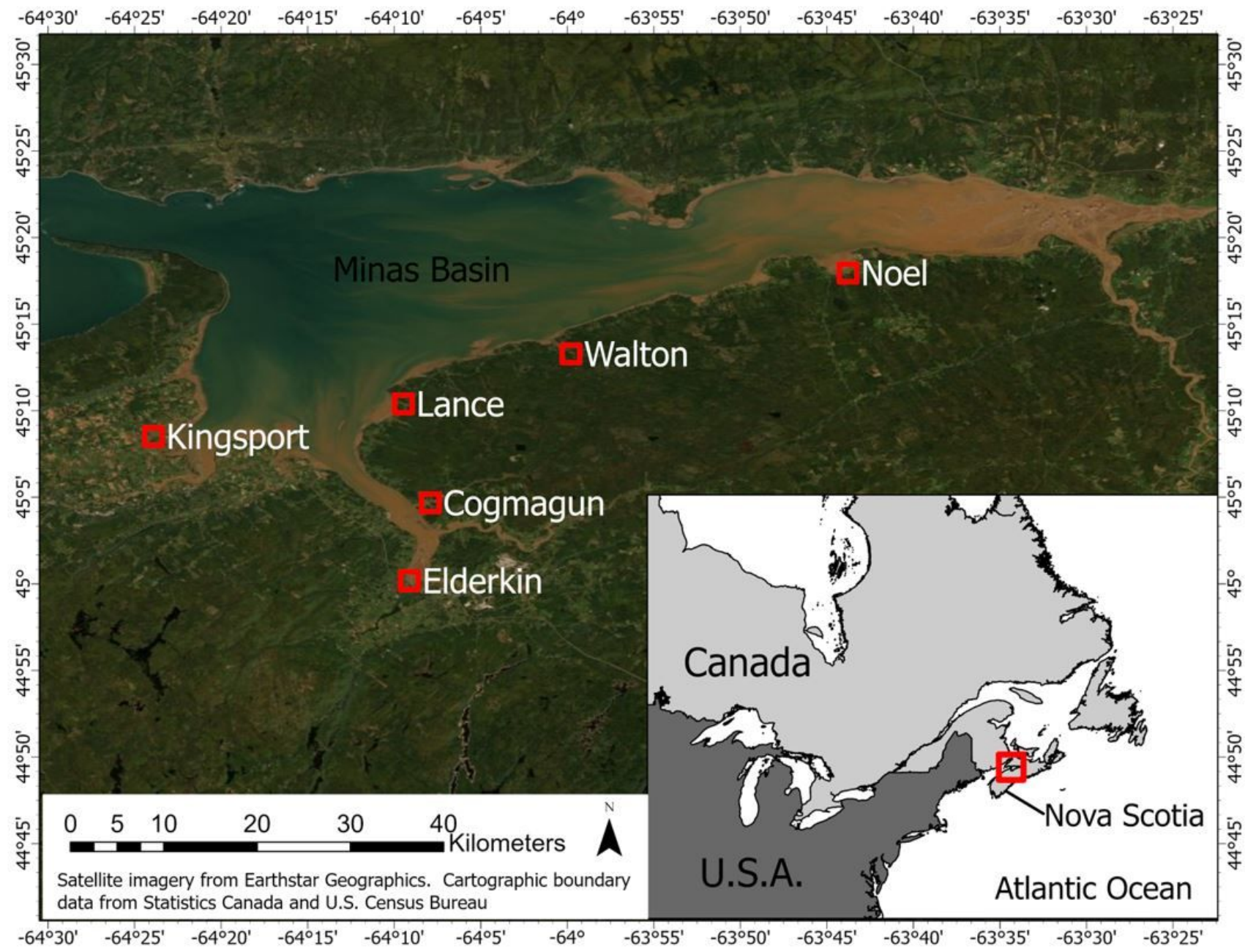

Figure 3

Site sites indicated by red boxes on the main map and study location indicated on the inset map. Ice was sampled at Elderkin, wrack was sampled there and at each other site. 


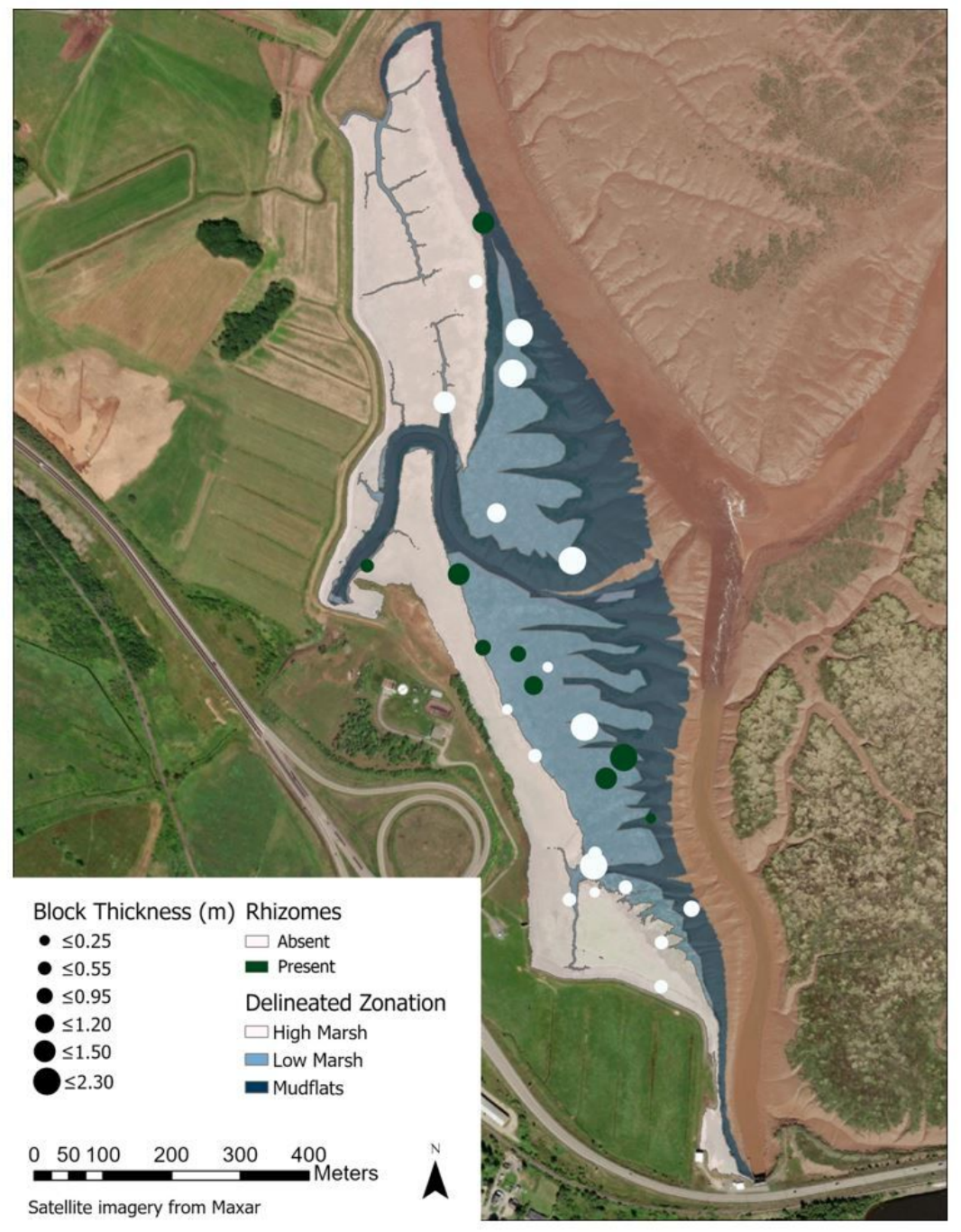

\section{Figure 4}

Delineated zones of the Elderkin marsh with locations of ice blocks sampled in March 2009 indicating which blocks contained rhizomes. 


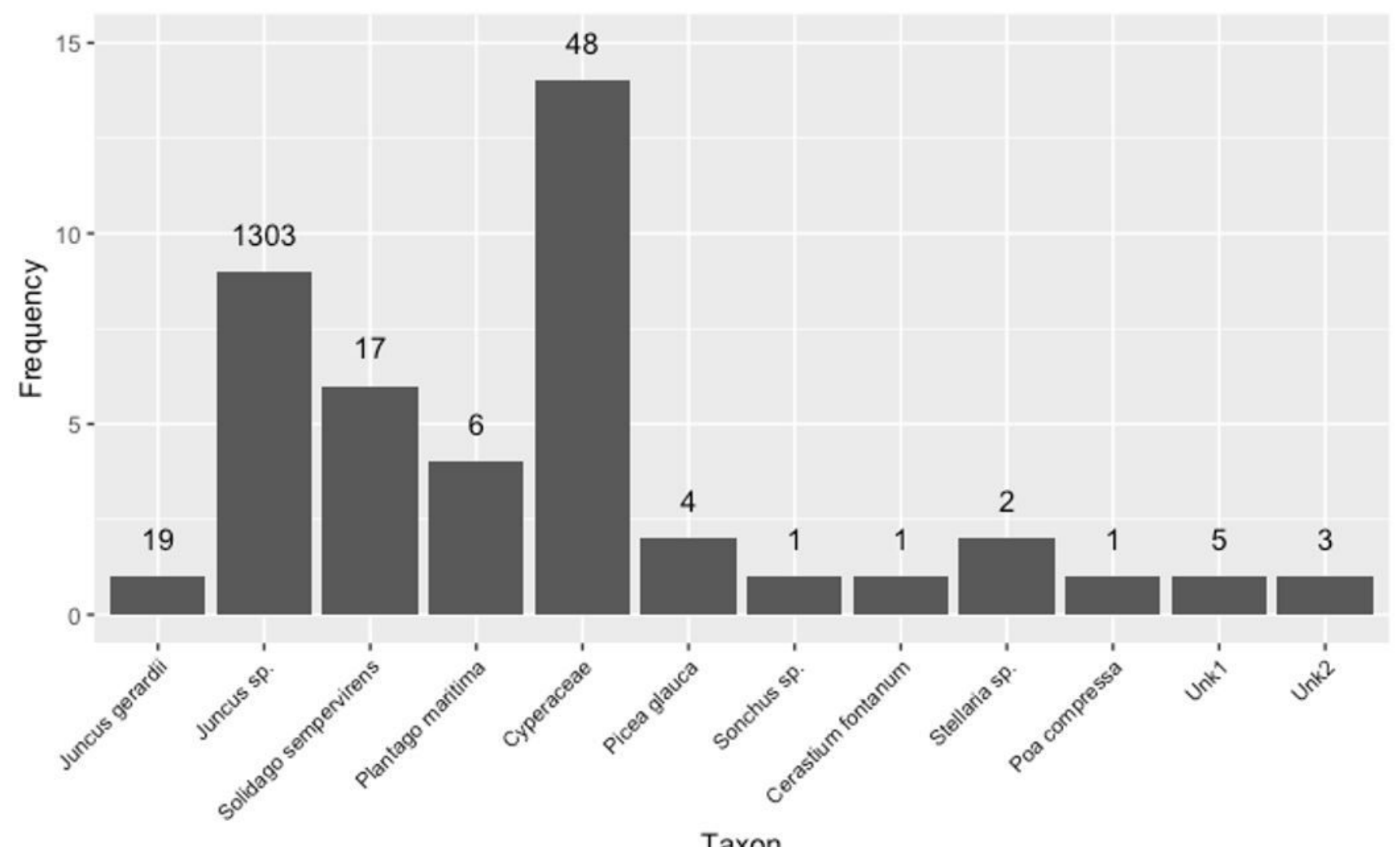

\section{Figure 5}

Germinated seeds from wrack collected from six sites in Bay of Fundy tidal marshes. Frequency indicates the number of samples the taxon was identified in (out of 18). The number above the bar indicates the total number of individual seeds germinated for each taxon. "Unk" refers to two taxa that could not be identified.

\section{Supplementary Files}

This is a list of supplementary files associated with this preprint. Click to download.

- Elderkinmarshicedata.xlsx 